\title{
Revenue Sharing and Structural Features of American Federalism
}

\author{
By DeIL S. WRight
}

\begin{abstract}
This article examines the impact of general revenue sharing on three structural features of American federalism: (1) governmental entities (number and employment); (2) institutions and actors' roles; and (3) behavioral perspectives. Revenue sharing will probably inhibit the further proliferation of special districts, sustain some townships that might atrophy, increase public employment levels, and foster or accentuate the secular shift of state government toward a service-oriented component of the federal system. General revenue sharing is both a cause and an effect of pluralistic power patterns. It is an important resource for political-administrative generalists in counteracting the influence of functional or program specialists. The generalist coalition, however, exhibits fragile features when compared with the strengths of policy making subsystems in Washington. Existing competitive, taut, and tension-laden intergovernmental relationships are in part the product of participants' perceptions. General revenue sharing appears to have relaxed tense relations by altering behavioral perspectives.
\end{abstract}

Deil S. Wright received his A.B., M.P.A., and Ph.D. from the University of Michigan. He has taught at Wayne State University, the University of Iowa, the University of California at Berkeley (as visiting professor) and the University of North Carolina at Chapel Hill. He is currently Professor of Political Science and Research Professor, Institute for Research in Social Science at the University of North Carolina. He has authored and coauthored books, monographs, research reports, and articles in the fields of state and local government, public administration, public finance, and intergovernmental relations. 
HOR purposes of this discussion, the structural features of American federalism have been placed into three broad groupings. This simplified classification scheme sacrifices many nuances and finely textured aspects present in the complex patterns of American intergovernmental relations. It also interprets the term structure in a loose, unconventional sense. The threefold scheme allows and fosters attention to far-reaching, long range developments in United States federalism. Trends and tendencies are examined in the specific context of how they may or may not be affected by the forces set in motion by the adoption of the State and Local Fiscal Assistance Act of 1972, otherwise known as general revenue sharing.

The three structural categories used as organizing themes are: (1) governmental entities; (2) political institutions and actors; and (3) behavioral perspectives. Brief indications and descriptions of the three features follow.

Governmental entities refer to the units of government that exist and operate in the multijurisdictional framework of the United States political system. Units or types of governmental jurisdictions are the basic building blocks of American federalism. These units have.legal-corporate existence, functional distinctiveness, and political significance that compel attention in any treatment of United States federalism. The conventional categories of governmental entities are, in addition to the national government: states, counties, municipalities or towns, townships, school districts and special districts.

A second structural feature of United States federalism is the re- lationship among and between major political institutions and their leading actors. The political institutions on which this article centers are the chief executive, the legislative branch, and the administrative establishment. The primary institutional actors considered are: elected executives, legislators, generalist administrators, and program professionals (sometimes called functional specialists). Note that political and administrative generalists have been singled out as actors apart from the program or functionally-oriented professionals. Special attention is paid to the past and present relationships between these two broad types of actors and to the effects of general revenue sharing on future role relationships.

A third structural characteristic, behavioral perspectives, emphasizes the views, outlooks and orientations of the participants in the interdependent, intergovernmental system. It may seem unusual, even a strain on the word structural, to apply the term to the perspectives of persons. Its utility and appropriateness is suggested on two grounds. First, the views or outlooks of governmental officials toward each other tend to form consistent patterns, that is, a structure of attitudes. Second, officials' views toward events, problems, policies, and each other shape or structure the probable behavior of these intergovernmental actors.

\section{GOVERNMENTAL ENTITIES: NuMBER OF UNITS}

What have been the trends in the number of governmental units in recent decades, and how may general revenue sharing affect these trends? Table 1 provides 1942 to 1972 figures on governmental enti- 
TABLE 1

Governmental. Units in The United States, 1942-1972

\begin{tabular}{lrrrrrr}
\hline \hline \multicolumn{1}{c}{ TYPE OF GoverNMENT } & \multicolumn{1}{c}{1942} & \multicolumn{1}{c}{1952} & \multicolumn{1}{c}{1957} & \multicolumn{1}{c}{1962} & 1967 & 1972 \\
\hline National government & 1 & 1 & 1 & 1 & 1 & 1 \\
States & 48 & 48 & 48 & 50 & 50 & 50 \\
Counties & 3,050 & 3,049 & 3,047 & 3,043 & 3,049 & 3,044 \\
Municipalities (towns) & 16,220 & 16,778 & 17,183 & 18,000 & 18,048 & 18,516 \\
Townships & 18,919 & 17,202 & 17,198 & 17,142 & 17,105 & 16,991 \\
Special districts & 8,299 & 12,319 & 14,405 & 18,323 & 21,264 & 23,886 \\
School districts & $\underline{108,579}$ & $\underline{67,346}$ & $\underline{50,446}$ & $\underline{34,678}$ & $\underline{21,782}$ & $\underline{15,780}$ \\
& 155,116 & 116,743 & 102,328 & 91,237 & 81,299 & 78,268 \\
\hline
\end{tabular}

SouRCES: U.S., Bureau of the Census, Governments in the United States 1, no. 1, 1957 Census of Governments; Governmental Units in 1972, Preliminary no. 1, 1972 Census of Governments.

ties by type of unit. Several trends are evident from scanning the row figures. The totals show a marked decrease from more than 150,000 units in 1942 to less than 80,000 in 1972. For our purposes it is necessary to look beyond the totals to the trends by type of unit.

It is apparent that the overall decline in units is explained by the disappearance of more than 90,000 school districts in 30 years. School districts, as units, are not eligible to receive general revenue sharing funds. It is therefore unlikely that the trend toward school consolidation, which may have run its course in any case, will be affected an iota by the presence or absence of revenue sharing.

A second pronounced trend among governmental units is the proclivity toward proliferation of special districts. Like school districts, special districts are ineligible for general revenue sharing funds, but, in contrast to school patterns, increases have been the consistent trend in special districts. The number has nearly tripled in three decades and almost doubled in two. During the recent short span of five years (1967 to 1972), more than 2,600 special districts were created, an increase in excess of 12 percent.

The enactment of revenue sharing legislation took account of special district proliferation, at least indirectly, by limiting its availability to a "unit of general government." Hence, the term general revenue sharing. To the degree that general revenue sharing was intended to forestall further jurisdictional proliferation, it is legitimate to raise questions about its efficacy in this respect. A case for revenue sharing's preventing proliferation rests on two major presumptions: (1) that most special districts have been created because of financial constraints, such as tax limitations; and (2) that revenue sharing has provided enough funds to ease the pressures toward jurisdictional proliferation. In this author's judgment, these conditions apply in sufficient measure to blunt the trend of increasing special districts. In short, I would predict fewer new special districts from 1972 to 1977 , although lesser increase will not all be attributable to general revenue sharing.

Fewer new units may be one slight impact of revenue sharing, despite the difficulty of demonstrat- 
ing it directly. But will revenue sharing lead to some reduction or consolidation of existing units? Here the prospects and predictions are especially elusive. A recent survey of 250 local governments disclosed that in six instances the existence of revenue sharing funds prompted consideration of changes in governmental jurisdiction, all in the direction of consolidation. ${ }^{1}$ Thus, about two percent of the units sampled were "considering" structural change. The discrepancy between consideration and actual achievement in the arena of jurisdictional change should be underscored. Significant reductions in the number of governmental entities because of general revenue sharing are therefore unlikely.

One other impact of revenue sharing on numbers of units remains for comment: Will it preserve any units that might otherwise disappear or be consolidated? Three types of jurisdictions are relevant to this question: counties, municipalities and townships. The durability, strength and familiarity of county government make it unlikely that revenue sharing will constitute a single or significant factor in preserving the existence of any county. The fate of county consolidations hinges on forces far more critical than the annual distributions of about $\$ 1.25$ billion among more than 3,000 counties. This sum represents less than nine percent of all general revenues (from own sources) of county governments in 1972 .

Will general revenue sharing promote the preservation of cities and townships? This question is often

1. Comptroller General of the United States, Revenue Sharing: Its Use by and Impact on Local Governments, 25 April 1974 (B-146285), p. 26. posed as encouraging the retention of uneconomical and inefficient jurisdictions. Judgments about which units fall in this suspect category are, of course, debatable and even volatile. The multiple and complex issues cannot be resolved in this discussion, but a few facts can be submitted and a prediction made.

Municipalities receive about 35 percent of the $\$ 5$ to 6 billion in annual revenue sharing distributions. This share, nearly $\$ 2$ billion, is approximately 8 percent of all general revenue raised by municipalities from their own sources in 1972. The existence of this marginal but noteworthy proportion could affect the inclinations of officials in a small number of jurisdictions to resist efforts to consolidate or eliminate their municipalities. Indeed, the trend for 30 years has been a modest, consistent increase in the number of municipalities through new incorporations. With few exceptions, these new cities have been created within Standard Metropolitan Statistical Areas (SMSAs). The effects of revenue sharing on the number of municipalities is seen as very slight and marginal. It is improbable that revenue sharing will promote any new incorporations, but in a few instances it may be a peripheral factor in promoting the preservation of a few towns or cities.

The township is the only type of general government unit that has shown a consistent decline over three decades. Nearly 2,000 townships have ceased to exist as entities. This decline is more a function of Census Bureau definitions and judgments than governmental restructuring and consolidation. Townships, which are concentrated in the North Central states, have long been considered remnants of surveyors' 
maps. With the exception of a few located in suburban areas, townships have been on the decline. General revenue sharing legislation is channeling about $\$ 250 \mathrm{mil}$ lion annually to townships. This is nearly 10 percent of all township general revenues from own sources in 1972. Among all types of governmental entities, revenue sharing will most likely have its greatest impact on townships insofar as affecting trends in numbers of units. An identifiable result of revenue sharing will probably be to arrest a decline in the number of townships. The merits of this result, if accurately predicted, are beyond the immediate scope of this discussion.

\section{GOVERNMENTAL ENTITIES: EMPLOYMENT}

The number of entities is but one feature of governmental structure. A second is the size and relative magnitude of governmental types as measured by full-time employment. Available data permit the charting of employment by major types of entities for more than two decades. Figure 1 depicts the respective patterns by jurisdictional type from 1951 through 1973. The logarithmic scale allows comparisons of rates of change, according to the slope of trend lines, but still identifies absolute levels of full-time equivalent employment.

Table 2 presents in tabular form the two-decade trends and the levels for the most recent year available (1973). For those not already familiar with employment patterns, figure 1 and table 2 make apparent the prominence and dominance of local governments in the public sector. Because of small magnitudes, the employment levels and trends for townships and special districts are omitted for figure 1.
More than half of the 12.6 million public employees in 1973 are with local governments. Furthermore, nearly half of all local employment is in school districts. One other observation about current levels should be noted: the employment levels of national and state governments have approached each other, and, if the current trend continues, state employment will soon exceed that of the national government.

Changes in employment during the past decade are indicative of secular shifts in the structure of relations among governmental levels. According to Census Bureau computations, there have been marked contrasts in the year-to-year (annual) percentage changes in public employment, depending on the type of jurisdiction. The annual percentage increases from 1962 to 1972 were: counties, 4.5 percent; municipalities, 3.1 percent; townships, 4.1 percent; special districts, 4.6 percent; school districts, 4.7 percent; and state governments, 5.3 percent. $^{2}$

During the recent decade of growth, the rate of county employment substantially exceeded the growth rate for municipalities. The contrasting growth rates of the two types of entities undoubtedly reflect the impact of suburban growth throughout the nation. More specifically they reveal the role of county governments, especially those in SMSAs, in responding to demands for urban-type services. At the local level the growth rate for special districts (4.6 percent) slightly exceeds the county rate and, not surprisingly, the rate for school employment is the highest for this 1962 to 1972 period. The 4.7 average annual increase resulted from the school population surge during this decade.

2. U.S., Bureau of the Census, Public Employment in 1973, Series GE73-No. 1, p. 2. 
FIGURE 1

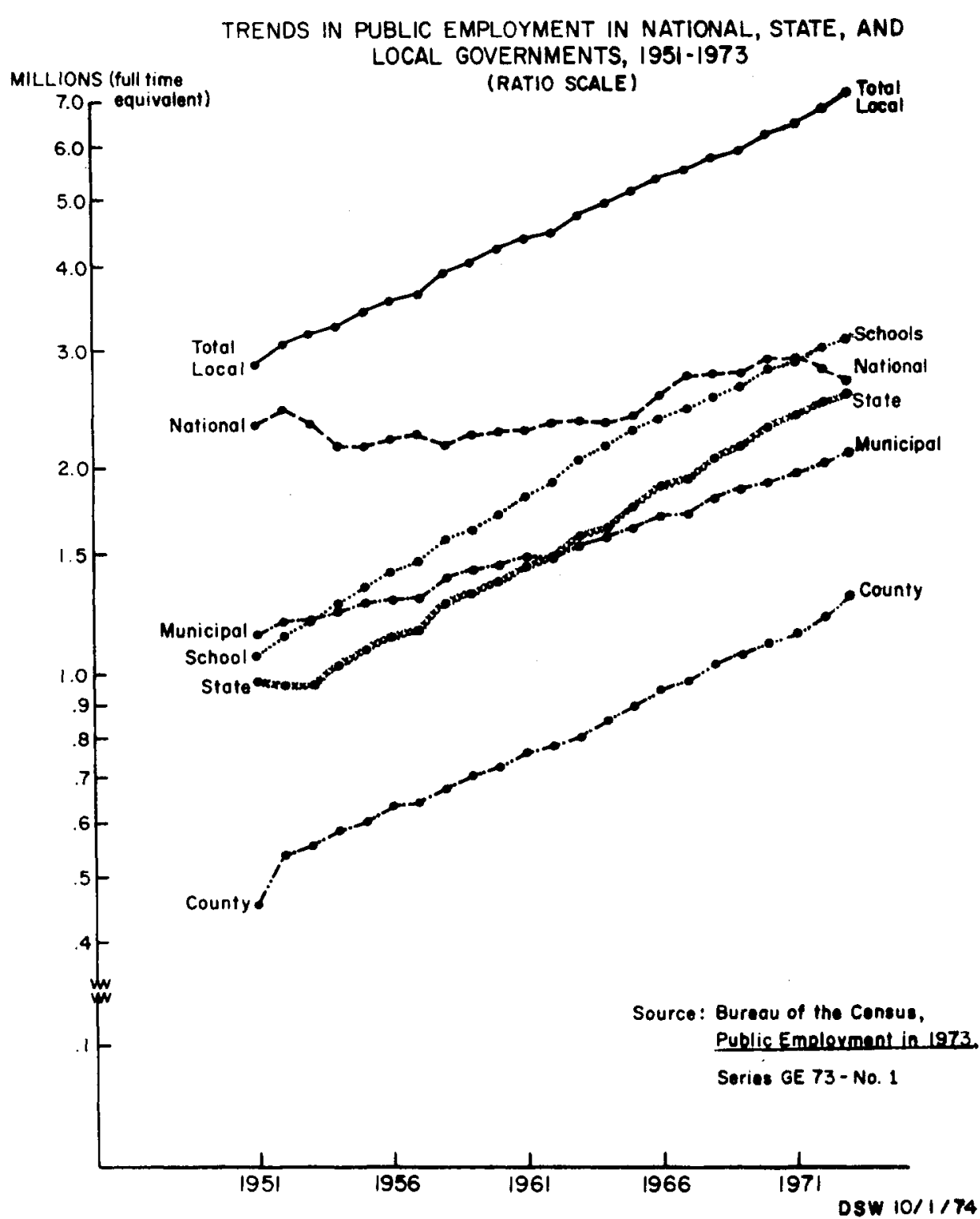

Perhaps the most noteworthy feature of the above percentages is the figure for state government. By growing at 5.3 percent per year, the states were the most dynamic component of public sector employment. This rate of increase, as well as the confluence of numerous other forces in the intergovernmental system, led the various observers to argue that the states are "where the action is." The upward thrust of state activity, as represented by employment, can be observed from the 
TABLE 2

Full-Time Equivalent EMPLOYMENT ay Governmental JuRisdiction Selected Years, 1952-1973

(in millions)

\begin{tabular}{lrrrr}
\hline TYPE OF GOVERNMENT & 1952 & 1962 & 1972 & 1973 \\
\hline State & 1.0 & 1.5 & 2.5 & 2.6 \\
Total local & 3.1 & 4.5 & 6.7 & 7.0 \\
counties & .5 & .8 & 1.2 & 1.3 \\
municipalities & 1.2 & 1.5 & 2.0 & 2.1 \\
townships & .1 & .1 & .2 & .2 \\
special districts &. .1 & .2 & .3 & .3 \\
school districts & 1.1 & 1.9 & 3.0 & 3.1 \\
\hline
\end{tabular}

Source: U.S., Bureau of the Census, Public Employment in 1973, Series GE73-No. 1, p. 8.

trend lines in figure 1 where visual comparisons of contrasting recent trends are permitted. The slope of the state line is at a greater incline than those for other government jurisdictions.

In what way (s) is revenue sharing likely to affect trends in the respective roles of governmental units and the structure of public employment? The first general conclusion is that it will affect trends only marginally. That is, revenue sharing is about five percent of state and local budgets. This proportion is diluted even further in its impact on employment levels when revenue sharing funds are used for capital outlay rather than for operating purposes. Only in the latter case is there substantial and continuing impact on public employment.

Apart from a modest or marginal impact, will there be any differential employment effects of revenue sharing by type or unit? The following predictions seem likely differential effects:

1. Jurisdictions under the greatest financial pressure will use proportionately more money for operating purposes and produce proportionately greater increases in public employment.

2. Municipalities are more likely to use funds for operating purposes than are counties and townships, with an accompanying greater increase in public employment.

3. Larger jurisdictions are more likely than smaller units to use the money for operating (and public employment) purposes.

School districts and special districts are ineligible to receive revenue sharing funds; no capital outlay or operating and employment purposes by these types of units should be expected. Two sources may produce indirect effects from revenue sharing on school districts. First, state governments may decide to use some funds from revenue sharing for school purposes, either operating or capital outlay. Second, counties or cities are permitted, if they so choose, to spend revenue sharing money for school capital outlay. Restrictions in the law prohibit paying operating expenditures for school purposes.

Three predictions are offered above regarding the differential impact of revenue sharing monies as 
they may affect allocations for operating purposes and impact on public employment levels. Can the accuracy of these predictions be assessed within the short existence of revenue sharing? Initial short term data from six-months actual-use reports and annual employment figures allow a provisional assessment of the predictions.

The proportion of revenue sharing funds expended for operating purposes during the first six months of the program were: states, 94 percent; counties, 44 percent; cities, 56 percent; and townships, 52 percent. ${ }^{3}$ The differences among types of local units are not momentous. The larger proportion for cities is consistent with prediction 2 above, and also with prediction 1 if it is assumed that cities are more financially hard-pressed than counties or townships. There is evidence to suggest that this latter condition does apply.

How is it possible to explain the exceptionally high proportion (94 percent) that the states have allocated to operating outlays? Are the states under greater fiscal pressures than local units? This would not appear to be the case if reports about state surpluses are true, and especially the indication that in 1973 state governments reduced taxes by a net of $\$ 500$ million. ${ }^{4}$ There is,

3. U.S., Department of the Treasury, Office of Revenue Sharing, Revenue Sharing: The First Actual Use Reports, 1 March 1974, pp. $8-13$.

4. See, "Fiscal Affluence for State and Cities," New York Times, 3 December 1972; "Study Predicts Local Revenue Surplus," Washington Post, 1 October 1973; Tax Foundation, "State Tax Action in 1973," Tax Review 34, no. 9 (September 1973); Advisory Commission on Intergovernmental Relations, Information Exchange Service, "The 1972 State-Local Fiscal Surplus," No. 73-1 (January 1973). however, considerable evidence to show that the states have been in an intergovernmental fiscal vise during the past 10 or 15 years. The middleman role of the states in the federal system has subjected them to severe financial pressures from above (national) and below (local units). The pincers-type fiscal squeeze on the states derives from five fiscal dilemmas which the states have confronted and to which they have responded with herculean tax efforts. ${ }^{5}$

For example, between 1958 and 1972 state tax revenues increased from $\$ 14.9$ to $\$ 59.9$ billion, or a net rise of $\$ 45.0$ billion. During the same period, state aid to local units increased by $\$ 28.7$ billion, and state funds required to match rapidly rising federal aid increased by an estimated $\$ 16.0$ billion. $^{6}$ In effect, states made prodigious tax efforts, the apparent result of which was barely to match intergovernmental claimants from below and above.

One other data series confirms the distinctive fiscal role of the states and indicates the allocational pressures they have faced. Figures cited below are ratios of capital outlays to operating expenditures from 1963 to 1973 for direct spending by level of government. Table 3 provides the arrays of ratios by governmental level. During the decade, capital outlay/operating expenditure ratios for the national government ranged from 15 to 32 with no discernable trend. For all local units the ratio ranged from 29 to 22 with a modest and somewhat consistent trend downward. For the states, however,

5. Deil S. Wright and David E. Stephenson, "The States as Middlemen: Five Fiscal Dilemmas," State Government 47, no. 2 (Spring 1974), pp. 101-107.

6. Wright and Stephenson, "States as Middlemen." 
TABLE 3

Ratios of Capital Outlays to Operating EXPENDITURES for NATIONAL, STATE, AND LOCAL GOVERNMENTS, 1963-1973

\begin{tabular}{cccc}
\hline \hline Year & National & State & Local \\
\hline 1963 & 32 & 65 & 29 \\
1964 & 29 & 65 & 28 \\
1965 & 19 & 62 & 29 \\
1966 & 26 & 60 & 28 \\
1967 & 21 & 57 & 27 \\
1968 & 24 & 52 & 26 \\
1969 & 20 & 47 & 26 \\
1970 & 18 & 43 & 24 \\
1971 & 15 & 40 & 24 \\
1972 & 20 & 38 & 22 \\
1973 & 19 & 33 & 22 \\
\hline
\end{tabular}

SourCE: U.S., Bureau of the Census, Governmental Finances in 1972-73, Series GF 73-No. 5, Table 5; and previous years.

a major, consistent, and significant downward trend occurred.

These ratios identify a major turnabout in the character of state spending. In 1963 state capital outlays were nearly two-thirds of current operations expenditures. The actual amounts were, respectively, $\$ 8.1$ and $\$ 12.4$ billion. By 1973 the ratio was only one-third, and the amounts were $\$ 14.7$ billion for capital outlays and $\$ 44.8$ billion for current operations. In sum, the states have moved rapidly and dramatically from capital-intensive outlays to the support of service-intensive programs. This shift, combined with other forces, has produced the rapid increase in state-level employment.

The states' actual-use reports, showing more than 90 percent of revenue sharing allocated for current operations, supports one contention and one prediction. The first is that the states appear to remain under service-intensive pressures. Second, it seems that revenue sharing will permit, and perhaps accentuate, the trend away from capital-intensive state governments.

Annual employment data for 1973 do not provide a firm or clear base for assessing the differential impacts of revenue sharing on public employment among local entities. Perhaps the full effects of the infusion of revenue sharing funds are not reflected in the fall $1973 \mathrm{em}$ ployment data. All three eligible types of local jurisdictions substantially increased their employment levels in comparison to their 1962 to 1972 average. The 197273 percentage increases were: counties, 8.2 percent; cities, 4.7 percent; and townships, 7.4 percent. If these recent rates are compared, respectively, to the 1962 to 1972 trends, the resulting ratios are: counties, 1.8 ; cities, 1.5 ; and townships, 1.8. The ratios represent incremental shifts, or departures from trend.

These figures provide the basis for two observations. First, the one-year availability of revenue sharing has contributed to greater growth rates in local public employment trends. Second, there do not appear to be sharp differences in the incremental effects among types of local units.

One remaining prediction, number 3 , remains for comment. We observed that larger jurisdictions will probably use general revenue sharing funds more for operating purposes, and this will subsequently be reflected in higher employment growth rates. Data on employment increases by size of unit are not available, but information from the first actual-use reports lends provisional support to the prediction. According to the analysis of the reported data, "The general pattern .. . supports the conclusion that larger units of government, especially counties and cities, have 
spent a greater proportion of their revenue sharing funds for operatingmaintenance uses while smaller units have spent a larger proportion on capital items."7

\section{INSTITUTIONAL AND ACTORS' ROLES}

The American political system has been aptly described as one of dispersed power. The two major structural (and constitutional) means of parceling out political power are: (1) separation of powers, and (2) federalism. The former usually draws attention to the national executive, legislative and judicial branches and covers not only the partition of power, but also accompanying checks and balances. The latter interlevel distribution of authority, sometimes called division of powers, has usually been approached from the standpoint of centralization-decentralization.

Many analyses of United States federalism have emphasized centralizing trends, and often these are based on a conception of power distribution similar to that of a zerosum game. That is, if one level, player, or intergovernmental actor gains power, that gain is compensated by an equivalent loss of power by another participant. It is the intent of this brief discussion of institutional power distributions, actor roles, and revenue sharing to suggest: (1) the need for integrating any analysis of federalism with that of separation of powers; and (b) the limitations of the zero-sum model to intergovernmental relations.

It has been a common practice among students of federalism to employ metaphors to clarify and simplify the nature of interlevel re-

7. Office of Revenue Sharing, First Actual Use Reports, p. 23. lationships. Thus, so-called layer cake federalism stood for the separatism and exclusive powers doctrines that were thought to describe United States intergovernmental relations during the 19th and early 20th centuries. The layer cake characterization was succeeded by the marble cake metaphor. Studies of United States intergovernmental relations in the 1940s and 1950s disclosed a complex, inextricable intertwining of relationships among jurisdictions and intensive interaction among public officials from the various jurisdictions. ${ }^{8}$

New metaphors have been proposed and explored as more graphic and attention-demanding ways of coping with the complexities and challenges that confront the nation. The one submitted here as the more accurate and current characterization is so-called picket fence federalism. The term is drawn from the text of Terry Sanford's Storm Over the States. ${ }^{9}$ Sanford describes the difficulties he faced as governor of North Carolina in controlling, coordinating, and coping with the influence of program professionals and their like-minded professional allies at the national and local levels. These programmatic alliances were, to Sanford, like so many vertical pickets laid upon the horizontal slats of the national, state and local governments. A graphic representation of Sanford's metaphor is provided by figure 2 . The vertical links consist of shared loyalties by pro-

8. Edward W. Weidner, Intergovernmental Relations as seen by Public Officials (Minneapolis: University of Minnesota Press, 1960); Morton Grodzins, The American System: A New View of Government in the United States, ed. Daniel J. Elazar (Chicago: Rand McNally, 1966).

9. Terry Sanford, Storm Over the States (New York: McGraw Hill, 1967), p. 80. 


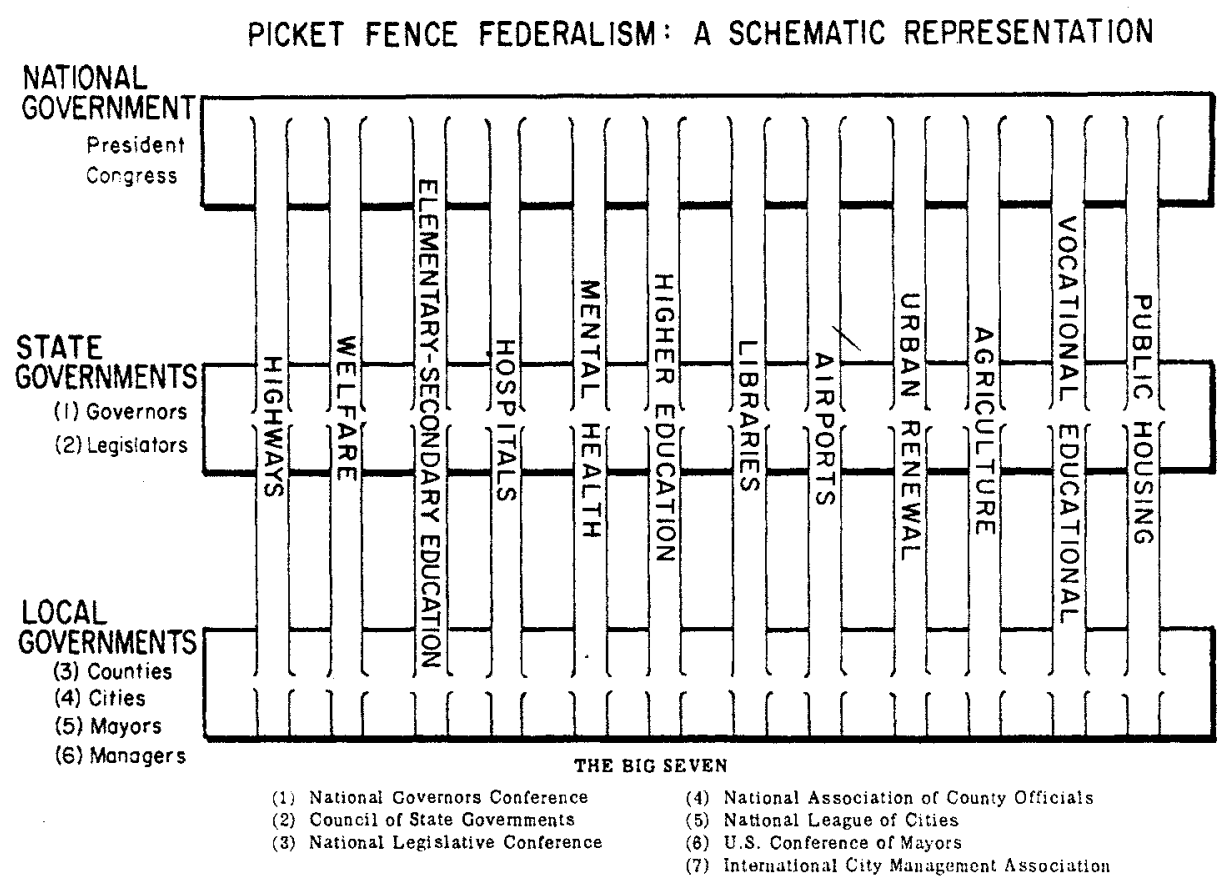

(C) Copyright 1974

Deil S. Wright

DSW 6/15/74

gram professionals that ignore or transcend the level of government at which they are currently employed. Perhaps the most potent connector creating and confirming the vertical alliances has been the federal categorical grant-in-aid.

Elsewhere this author has labeled the picket fence phase of intergovernmental relations so aptly described by Sanford as "competitive."10 The competition is twofold. First, there is competition between and among the program professionals, as for funds, jurisdiction, program primacy and political support. Second, and of greater significance, is the competition between the program professionals and the

10. Deil S. Wright, "Intergovernmental Relations: An Analytic Overview," THE ANNALS 416 (November 1974), pp. 1-16. governing generalists, that is, legislators and chief executives. The executives include both elected and appointed officials - governors and state budget directors, mayors and city managers, elected county executives and county managers.

The contrast in orientations between program professionals and governing generalists is strong and significant. The generalists are oriented primarily toward a level-ofgovernment orientation. They normally do not neglect or disparage program considerations, but their prime roles are coordination, control, and securing balance among programs. This frequently sets them in opposition to program professionals, regardless of level.

The character of the cleavage between the two sets of actors has been described in various ways by both 
participants and semi-detached observers. A city manager once conveyed to the author that his city was "little more than a battleground among contesting federal agencies and I sit here like a spectator in the stands watching them fight." Another quotation, less influenced by the heat of battle, came from Senator Muskie-not, by chance, a former governor. "The picture, then, is one of too much tension and conflict rather than coordination and cooperation all along the line of administration - from top Federal policymakers and administrators to the state and local professional administrators and elected officials."11

What has revenue sharing to do with this abstract and admittedly somewhat simplified version of institutional and actor roles? The relationship is both strong and one of cause as well as effect. General revenue sharing can be viewed as the dollar representation of an alliance among generalists, especially executives, at all levels to counteract the accumulated influence of the program professionals. In the framework of figure 2, revenue sharing can be seen as a contest between the Big Seven, representing the generalists, and the "determined dozen."

The latter is merely a figurative reference to the numerous sets of program professionals typified by the 12 vertical "pickets" shown in figure 2. The precise number of vertical functional alliances is somewhat indeterminate, although it is thought to be associated with the number of categorical grant-in-aid programs which are currently esti-

11. U.S., Congress, Senate, Congressional Record, 89th Cong., 2nd sess., 1966, 112, p. 6834 . mated at 450 . The Big Seven refers to the seven associations listed at the bottom of figure 2. Collectively these associations of public officials are also called the Public Interest Groups, or PIGs. ${ }^{12}$ The PIGs share a generalist, level-of-government orientation with strong executivecentered tendencies.

General revenue sharing was, in large measure, "caused" by the executive-generalist coalition described above. ${ }^{13}$ No one can read the accounts of its passage and the testimony of state and local executives at congressional hearings without appreciating the effectiveness with which the generalists sold the case for revenue sharing. The natural question in the context of this predictive-oriented analysis is what effect general revenue sharing will have on the continued viability of the executive coalition. There are several dimensions to the question, but only two deserve comment here.

First, will revenue sharing in its initial five-year form provide statelocal generalists, particularly executives, with notably increased leverage in relation to program professionals? Both logic and fragmentary evidence suggest that it has enhanced the role of executives in determining priorities and influencing policy. There is some doubt as to whether the same can be said for legislators such as state representatives, county commissioners and city councilmen.

The critical question, however, is how the recent and current experience with revenue sharing is

12. See, "Public Interest Groups," Public Management 53, no. 12 (December 1971); and Richard E. Thompson, Revenue Sharing: A New Era in Federalism (Revenue Sharing Advisory Service, 1973), pp. 45-53. 123. 
linked to generalists' behavior in the near future. The revenue sharing legislation expires in 1976. Will this role advantage and other gains from revenue sharing be of sufficient magnitude to provide a powerful impetus among generalists to press for extension of the legislation beyond 1976?

There is reason to doubt that the advantages from revenue sharing to executives and legislators are sufficiently strong to generate the same intensity of pressure that resulted in the 1972 act. Much will hinge on unknown political conditions in 1976, but a necessary condition for the extension of revenue sharing is the potency of the executive-generalist alliance. In 1972 the need for money was the cement that held governors, mayors, and other officials of all political hues and conditions together in support of general revenue sharing. Monetary need alone will probably be insufficient to generate support for revenue sharing extension. An important additional element for binding the generalist alliance will be institutional - a stronger conception of their common role.

There is a second dimension of the institutional question regarding the position of the generalist coalition. Its character, concerns, and potential strength have been discussed largely in terms of its base at the state and local levels. Its capabilities for impacting on policy making at the national level must also be assessed. Here we move considerably beyond the short term question of whether revenue sharing will be renewed. Will the generalist coalition, born in part by negative reactions to categorical grants and flexing its muscles on the passage of revenue sharing, reach political maturity on the pluralistic and frag- mented Washington scene? Of course, this question cannot be answered now. Our present aim is modest and minimal, namely, to provide a clearer understanding of the problem.

The starting point of this analysis is a significant but unappreciated proposition put forward by the temporary (1953-55) Commission on Intergovernmental Relations. In a chapter discussing "National Responsibilities," the commission agreed on the summary assertion that, "In brief, the policymaking authorities of the National Government are for most purposes the arbiters of the federal system."14 The national "authorities" referred to were the courts, the president, Congress and the administrative agencies of the executive branch. Granting the validity of the commission's contention leads us in search of a model or generalized description of policy making at the national level. Such a model would help identify and assess any prospects for influence exerted by the generalist coalition of state-local officials.

One well-documented and widely accepted model of national policy making is the so-called policy subsystem. Studies in various program and policy areas have identified the strength of relationships among administrative agencies, congressional committees or subcommittees, interest or clientele groups, and professional associations. ${ }^{15}$

14. Commission on Intergovernmental Relations, Report to the President for Transmittal to Congress (June 1955), p. 59.

15. J. Leiper Freeman, The Political Process: Executive Bureau-Legislative Committee Relations (New York: Random House, 1965); Lewis C. Gawthrop, Bureaucratic Behavior in the Executive Branch: An Analysis of Organizational Change (New York: Free 
The interactions among individuals from these four components constitute the policy making subsystem. The intensity and like-mindedness generated from these exchanges produce bureau autonomy, fragmentation, and pluralism at the national level.

From a program and organizational standpoint, the consequences of this pattern are that all significant phases of policy making except official approval fall within the domain of the policy making subsystem. The visual representation of the subsystem is shown in figure 3 . The diagram is entitled "Influences on National Policy Making and Administration" because it attempts to plot, map or identify the primary interacting sources and forces that affect outcomes on policy issues at the national level. The closed, cohesive, insulated and autonomous character of the relationships suggests several simplified terms for the subsystem: reinforcing rectangle, self-directing diamond, and solidified square.

The messages, if not all the implications, are clear: to impact on national policy making the generalist coalition must bypass, break, or coopt various elements of the policymaking subsystem. Opportunities for success by following any one or a combination of these three strategies depends on a large set of variables-historical, accidental, and otherwise. General revenue sharing can be viewed as a bypass strategy. Other generalist efforts, particularly those revolving around special revenue sharing (grant con-

Press-Macmillan, 1969); Francis E. Rourke, Bureaucracy, Politics, and Public Policy (Boston: Little, Brown \& Co., 1969); Harold Seidman, Politics, Position, and Power (New York: Oxford University Press, 1970). solidation) and grant reforms rely on cooptation strategies.

The prospects for frontal assaults to break up a subsystem are unlikely because of subsystem strengths. Those strengths derive from several sources, including: (1) the highly specialized nature of most administrative agencies; (2) the resistance by functional specialists to policy initiatives that will diminish their effective control; (3) the protective or paternalistic view taken by a congressional committee or subcommittee toward an agency under its jurisdiction; (4) the strength of congressional tradition in deferring to committee judgment; and (5) the links between the functional specialists at all governmental levels through (a) grantor-client relationships or (b) contacts and similar outlooks generated by common professional training and/or associations. The last item is a variant form of the picket fence vertical-alliance formulation with an added feature. The existence of professional associations, norms, and standards provides additional insulation for the policy making subsystem. It reinforces subsystem autonomy in intergovernmental programs through the separate or joint effects of horizontal (peergroup) forces.

To what extent will general revenue sharing contribute to a surge of influence on the national policy making landscape as described above? First, an earlier implication about the Public Interest Groups should be acknowledged. These associations of generalists, the Big Seven, are not newcomers, novices, or weaklings on the Potomac scene. Their existence, roles, and selective influence have been the subject of numerous commentaries and at 
FIGURE 3

INFLUENCES ON NATIONAL POLICY MAKING

AND ADMINISTRATION

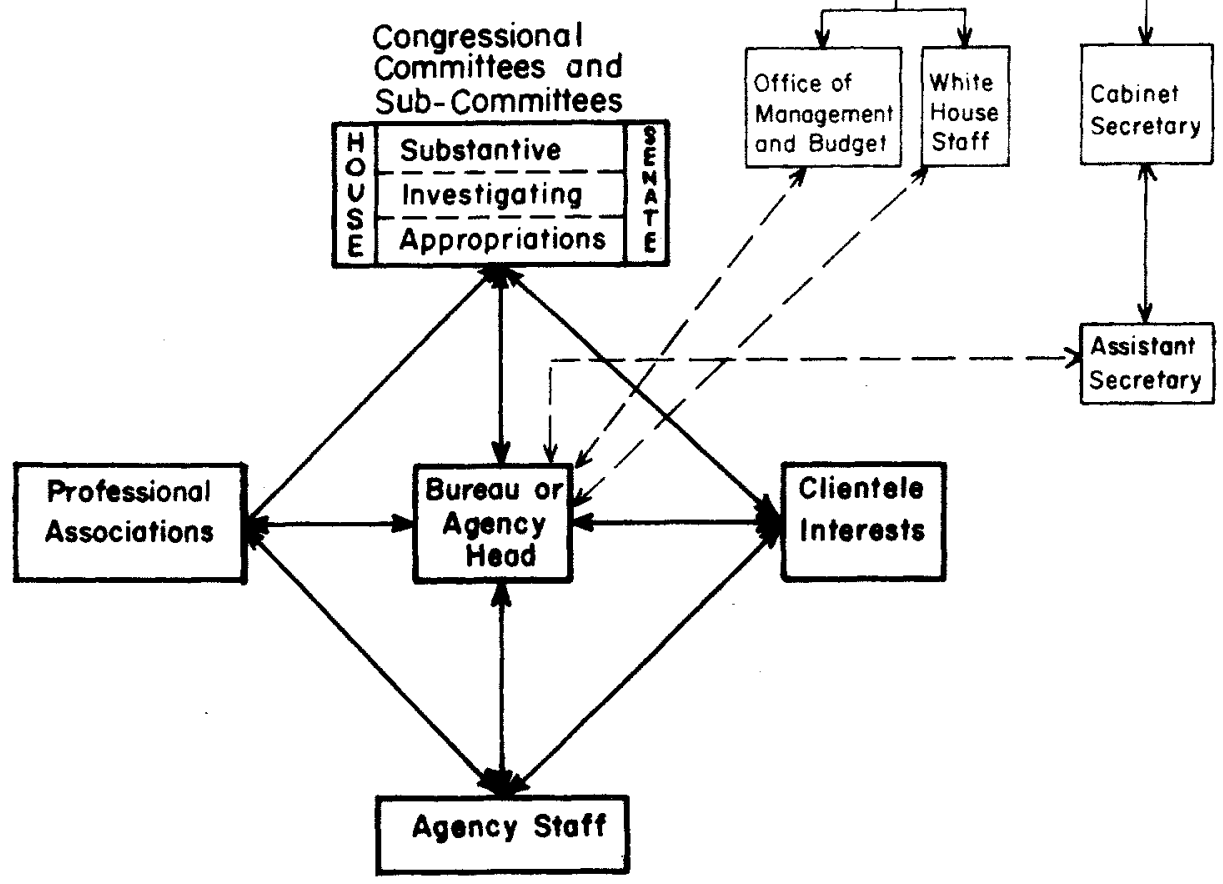

Solld lines indicate direct or primary influence.

(arrow indicates direction of influence)

$\longrightarrow \rightarrow$ Broken lines Indicate Indirect or secondary influences.

least two thoughtful appraisals. ${ }^{16}$ The concern here is how much "glue" revenue sharing has provided as a basis for holding the entire generalist coalition together and for pyramiding the influence exerted in the passage of the 1972 legislation.

16. Suzanne G. Farkas, Urban Lobbying: Mayors in the Federal Arena (New York: New York University Press, 1971); Donald H. Haider, When Governments Come to Washington: Governors, Mayors, and Intergovernmental Lobbying (New York: Free Press, 1974).
Without extensive elaboration and justification, I predict that revenue sharing will not significantly enhance the prospect for state-local leverage on policy making subsystems at the national level. Several factors contribute to this conclusion. Four prominent ones may be cited. First, there are great variations in jurisdictional size and needs, as well as officials' outlooks within each of the Public Interest Groups. Second, there are institutional strains between or among the associationsfor example, governor's conference 
relationships with the state legislators' association. Third is the absence of a unifying ideology, policy focus or constituency (apart from more dollars), as seen in the lack of urbanism as a binding political base for the passage of legislation. ${ }^{17}$ A fourth limitation is the institutional incapacity of Congress to assess and act on intergovernmental questions, particularly as national actions produce multiple-order effects throughout the complex interdependent federal system. For example, the House and Senate committees on intergovernmental relations are subcommittees of parent committees on government operations whose jurisdiction is posterior to substantive legislation and involves mainly legislative oversight.

In an unusual and striking power shift, however, the House Subcommittee on Intergovernmental Relations has obtained jurisdiction over renewal of general revenue sharing. Whether this subcommittee desires or can wield "generalist" authority remains to be seen.

\section{Behavioral Perspectives}

Examined above are governmental entities as well as institutional and role relationships as structural features of federalism in relation to revenue sharing. The following treatment of behavioral perspectives is briefer in focus and compass for several reasons, not the least of which is a limited amount of data on officials' perceptions of their own and others' behavior in intergovernmental contexts. The scope and significance of behavioral perspectives are of such magnitude that,

17. Frederic N. Cleaveland, "Congress and Urban Problems: Legislating for Urban Areas," Journal of Politics 28, no. 2 (May 1966), pp. 289 -307. in the brief space remaining, little more can be done than to call attention to the topic and convey an appreciation for its prominence in intergovernmental affairs.

A few surveys are extant that report distributions, invariably at one point in time, on how some officials view the actions and responses of others. In 1965 the Senate Subcommittee on Intergovernmental Relations posed an extensive battery of questions to more than 100 national administrators of federal grant programs. ${ }^{18}$ Two perspectives relevant to this discussion were notable among a wide-ranging set of findings from the survey. First, the federal officials expressed doubts and made negative comments about the professional competence and commitment of state and local administrators. Second, and more significantly, the subcommittee report noted: "Elected policymakers at the state and local level [generalists] were identified-either clearly or obliquely - as the villains in the drama of intergovernmental personnel relationships. The national administrators opposed giving these elected officials greater flexibility, which might result in needed changes in state and local personnel policies."19

A second survey, also taken in 1965, examined the attitudes of city managers in large council-manager cities. It specifically requested managers' views on the cooperativeness and results of contacts with officials at the national and state levels. The managers reported that

18. U.S., Senate, Subcommittee on Intergovernmental Relations, The Federal System as seen by Federal Aid Officials, 89th Cong., 1st sess. (Committee Print), 15 December 1965.

19. Subcommittee on Intergovernmental Relations, Federal System, p. 13. 
national officials were slightly more cooperative than state officials. ${ }^{20}$ When the results of intergovernmental contacts were evaluated, however, the relationships with national officials came out clearly more favorable than those with the state. Essentially similar findings were disclosed by a more recent study. ${ }^{21}$ Of 802 chief administrative officers responding to a 1969 survey, 38 percent reported that the federal government was more helpful in dealing with city problems. This contrasted with 21 percent indicating state officials were more helpful. Significantly, 27 percent reported that neither federal nor state officials were helpful. This last substantial proportion is probably an indication of the tension, rivalry and dissatisfaction present in the mazes of intergovernmental interactions.

Selective perspectives of national and local officials provide touchpoints in two of the three major planes of government. A few data points have also been established within the third plane, state government. Two or three attitude elements are especially noteworthy among top state administrators. For example, approximately 90 percent of state agency heads indicated either strong or moderate agreement that "it is very important that relationships between the national government and local units be channeled through the states." 22

20. Deil S. Wright, "Intergovernmental Relations in Large Council-Manager Cities," American Politics Quarterly 1, no. 2 (April 1973), p. 168.

21. International City Management Association, "Federal, State, Local Relationships," Urban Data Service 1, no. 12 (December 1969), p. 4.

22. Deil S. Wright, Federal Grants-in-Aid: Perspectives and Alternatives (Washington, D.C.: American Enterprise Institute, 1968), p. 124.
State officials exhibit, in this response pattern and in others, a "strong state" bias. The states and their officials, according to this view, are not merely intermediaries, middlemen or facilitators, but are keystones in arches forming the intergovernmental system.

Responses by state administrators to other questions revealed the presence of substantial negative or less favorable attitudes toward national and local officials. For example, nearly one-third disagreed with a statement suggesting that more authority and discretion be granted to local units of government. ${ }^{23} \mathrm{Gen}$ erally speaking, it is fair to say that state administrators indicated a substantial degree of doubt or skepticism about the views of intergovernmental actors at other levels.

These data identify within the three planes of governments the attitudes of tension, doubt, skepticism and concern present among one set of actors as they perceive intergovernmental actors in the other planes. There is a graphic approach to portraying the presence of the contrasting and competitive features present in the participants' perspectives described above. Figure 4 shows visually how national, state and local officials perceive the position and perspectives of the other participants in the intergovernmental bargaining-exchange process. The perspectives are diagrammed by the inverted-pyramid, diamond, and hourglass shapes. Each geometric pattern is a simplified representation of how a national, state or local official sees his own and other participants' perspectives.

For example, national officials judge their own views of problems

23. Wright, Federal Grants-in-Aid, p. 124. 
FIGURE 4

\section{INTERGOVERNMENTAL PERSPECTIVES: Officials' Outlook on The Federal System}

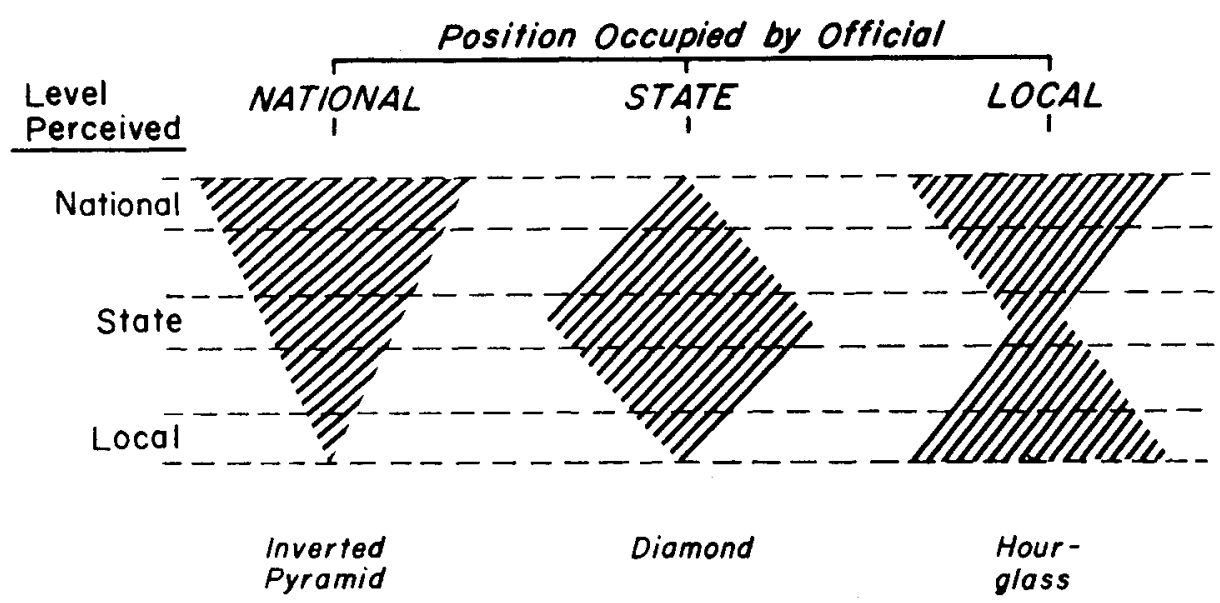

OCopyright: Deil S. Wright

DSW $6 / 15 / 71$

and policies as broad, extensive, circumspect and wide-ranging. When national officials assess the outlooks of state-level officials, they judge them as having more limited and narrower perspectives, ones that do not match the breadth, scope and quality of the ones they, the national officials, hold. National officials see local officials as holding a highly restricted, particularistic, even parochial set of perspectives. Local officials might be caricatured as "pipsqueak mayors" or "fly-bynight city managers." A less extreme but real-life occurrence of this pattern of perceptions surfaced shortly after the 1967 Detroit riot. A mid- level federal career official told Governor George Romney of Michigan and Mayor Jerome Cavanagh of Detroit that he knew better than they the likely causes and cures for Detroit's community conflagration.

State officials' perspectives form a diamond shape. They judge their own positions and outlooks as wideranging, potent, and broadly appropriate to the problems they face. Put differently, state officials see themselves sitting athwart the federal system. They see the views of national officials as constricted, narrow, and inappropriately attuned to the special circumstances and conditions of their particular state. Like- 
wise, state officials view the perspectives of local officials as limited, particularistic, and insufficiently broad in scope.

At the local level, intergovernmental perspectives conform to an hourglass shape. Local officials see common and compatibly broad outlooks shared by local and national participants; but at the state level they see narrow and limiting perspectives as dominant. This fits the frequently mentioned charge by local officials that the states are the bottlenecks of the entire system. An alternative, hydraulic-oriented criticism is that the states are funnels rather than tunnels. The constricted character of the states as conduits, according to local officials, helps explain the increased bypassing of the states in direct national-local flows of funds. These direct nationallocal dollars are estimated at about $\$ 6$ billion in 1974, excluding general revenue sharing.

These graphic characterizations of officials' perspectives are unquestionably crude and insufficiently attentive to variations by types of officials and the diversity among the units. The prime point is not to offer the diagrams as uniform and invariant descriptions but to emphasize the presence of contrasting outlooks among differently situated officials. Equally important is the degree to which each participant sees the others as having outlooks different from his own. The aggregate effect of these multiple and contrasting perspectives is a pattern of cleavages and competition. This can be noted visually if all three geometric shapes are overlaid. The result is a jagged jumble of lines and patterns producing the tension and rivalry labeled above as the current competitive phase of intergovernmental relations. Stated dif- ferently, there is a great deal of tightness in the system and a lack of slack resources by which the taut sinews of the system can be eased.

In the framework of the above formulation, revenue sharing has undoubtedly made a major contribution to easing or loosening the pressures on beleaguered state and local officials. In the cute and only half-jesting quip of one mayor, "Revenue sharing is my security blanket!" Almost by definition, general revenue sharing makes an important contribution to a relaxation of intergovernmental tensions. In the geometry of officials' perspectives depicted in figure 4, it should help round off the sharp points present in attitude patterns. To that extent revenue sharing has had, and will continue to have, positive effects on the structure of officials' intergovernmental perspectives.

\section{CONCLUSION}

Three structural features of American federalism are examined above in an effort to assess and predict the impact of general revenue sharing. The three structural characteristics are: (1) governmental entities; (2) institutions and actor roles; and (3) behavioral perspectives.

The probable short and long term effects of general revenue sharing on the number of governmental units are modest and marginal. By favoring units of general government, revenue sharing may blunt the proliferation of special districts. At the same time, it will likely have a preservative effect on some townships that might otherwise atrophy and disappear as operating entities.

The effects of revenue sharing on public employment are noteworthy in three respects. First, there is a 
positive correlation between the use of revenue sharing for operating purposes and the size of jurisdictions, as well as the degree of fiscal pressure on units. Second, operating outlays are reflected more directly in public employment increases, and a recognizable rise in employment did occur even in the first year of revenue sharing. Third, revenue sharing is likely to foster and even accentuate the secular shift of state government from a capital-intensive to a service-intensive component of the federal system.

General revenue sharing is both a cause and an effect of the pluralistic and fragmented patterns present in the structures of separation of powers and federalism. The fragmented features of federalism revolve around a cleavage between political-administrative generalists and functional or programmatic specialists. Revenue sharing is the generalists' answer to the accretions of influence by the specialists. There is considerable doubt as to whether it has provided a firm base from which the executive-generalist coalition can mount sufficient efforts to extend revenue sharing and accumulate influence to apply to other issues. The fragile features of the generalist orientation are shown in sharper relief when compared and contrasted with the policy making subsystem at the national level. The autonomy, insulation and strength of the reinforcing rectangle are important barriers to the potency of the Public Interest Groups on the Potomac scene.

Perhaps the most abstract and unappreciated effect of general revenue sharing has been some reduction in the tension, competition and rivalry pervading the relationships among intergovernmental actors. Patterns of intergovernmental perspectives exacerbate taut relationships. Revenue sharing has furnished and, if extended, will continue to provide slack or a cushion against which many of the harsher blows resulting from intergovernmental collisions will be appreciably softened. 